\title{
Közpénzügyi gazdálkodási folyamatok modellezése
}

\author{
Gubán Ákos' - Mezei Zoltán² \\ ${ }^{1}$ Budapesti Gazdasági Egyetem -2 Pécsi Tudományegyetem
}

\begin{abstract}
A TANULMÁNY CÉLJA
A gazdálkodási rendszerekben áramló objektumok/információk azonosítása és modellezése kiemelt jelentőségủ témakör a közpénzügyi adminisztrációs folyamatok hatékonyságának vizsgálata során. A „Szolgáltatási folyamatok javítása" c. kutatás egyik fontos tudományos eredménye a szolgáltatási folyamatokra alkalmazható matematikai modell megalkotása volt. Ez egy olyan heurisztikus szimuláción alapuló folyamatracionalizálási módszer, amely alkalmas nemcsak a folyamatok, hanem azok kapcsolódásaik, valamint ezen kapcsolódási csomópontok között áramló objektumok áramlásának hatékony újraszervezésére is.

A közpénzügyi folyamatok javítása nagy kihívást jelent a téma iránt érdeklődőknek, mert a közpénzügyi folyamatok nagyon szabályozottak. Ez egyrészt a jogszabályi környezetet jelenti, másrészt az azon alapuló kötött, belső szabályozást. Jelen a tanulmány célja a korábbi tudományos eredmények (szolgáltatási folyamatok javítása) felhasználásával, egy újabb - a közpénzügyi gazdálkodási rendszerhez jobban illeszkedő - matematikai alkalmazás bemutatása a hatékonyságjavítási témakörben.
\end{abstract}

\section{ALKALMAZOTT MÓDSZERTAN}

Az alkalmazott matematikai modellben elsősorban a csomópontokban végbemenő állapotváltozásokat jellemezzük folyamat- és áramlási aspektusból, ezáltal létrehozva egymásra nem ható transzformáció-rendszereket. Amennyiben az itt feltárt folyamatokat nem a hagyományos áramlási szempontból vizsgáljuk, hanem a belső állapotváltozások aspektusából, így kezelésük, javításuk ugyanazon a módon oldhatók meg, mint más sokkal rugalmasabb szolgáltatási folyamatrendszerek esetében.

\section{LEGFONTOSABB EREDMÉNYEK}

A folyamatelemzések azt mutatták, hogy a folyamatok objektumáramlási szempontból szeparáltan kezelhetők, azaz a független transzformációk modelljének használatával jelentősen javíthatjuk azokat. Ez az erősen szabályozott folyamatrendszerekre - közpénzügyi gazdálkodási folyamatokra - is igaz. A modell közpénzügyi gazdálkodási rendszerre történő leképezése azt eredményezi, hogy a felelős szervezeti egységek sokkal átláthatóbbak lesznek, és a folyamatjavítások is könnyebben elvégezhetők anélkül, hogy a jogszabályi előírásokat megszegnénk.

\section{GYAKORLATI JAVASLATOK}

A valós gazdálkodási rendszerekben egyetlen folyamatjavítási intézkedés sem képzelhető el izolált módon, hanem valamennyi érintett csomópontban el kell végezni a célzott beavatkozást. A szervezeti változások kivitelezésekor szükséges alkalmazni a független transzformációk modelljét, hogy kizárólag ,jó irányba” és „mellékhatás-mentesen” módosítsunk a folyamatokon.

Jelen tanulmány a bevezetést követően a szakirodalom áttekintésre fókuszál, a második része részletesen mutatja be a közpénzügyi szektorra adaptált hatékonyságjavítási eszközt. Végül összegzés zárja a tanulmányt.

Kulcsszavak: hatékonyságjavítás, közpénzügyi gazdálkodás, folyamat, objektumáramlás, modellezés

DOI: 10.15170/MM.2020.54.02.03

\footnotetext{
1 Budapesti Gazdasági Egyetem, tanszékvezető, főiskolai tanár, Guban.Akos@uni-bge.hu

2 Pécsi Tudományegyetem KTK, Ph.D., zoltanmezei@outlook.com
} 


\section{BEVEZETÉS INTRODUCTION}

A közpénzügyi gazdálkodási folyamatok javítása nagy kihívást jelent a téma iránt elkötelezett kutatóknak, mert a nemzetgazdaság e területe nagyon szabályozott. Ez egyrészt a jogszabályi környezetet jelenti, másrészt az arra épülö kötött, belső szabályozást. A legtöbb gondot egy gazdálkodási folyamatrendszer esetében a szükkeresztmetszeti csomópontok jelentik, mert ezekben várakozik, lassul vagy sérül leggyakrabban az objektum. Ezekre kiemelten kell fókuszálni, és a lehetséges folyamatjavításokat elsősorban itt elvégezni.

Jelen kutatás kiemelt célja lett megtalálni a folyamatjavítási lehetőséget a nem rugalmas keretek között. Ennek előfeltételeként korábban megalkotásra került egy olyan heurisztikus szimuláción alapuló folyamatracionalizálási módszer, amely a szolgáltatási folyamatok újraszervezésével alkalmas nemcsak a folyamatok, hanem azok kapcsolódásaik, valamint ezen kapcsolódási csomópontok között áramló objektumok áramlásának hatékony újraszervezésére is (Gubán - Kása 2014).

A cikkben megjelenő testreszabott módszertan kidolgozásával lehetőség nyílik a korábbi kutatás során elért tudományos eredmények alkalmazására a közpénzügyi gazdálkodási folyamatokban. A tanulmányban a közpénzügyi gazdálkodás fogalmát lehatároljuk a pénzügyi/számviteli adminisztrációs folyamatokra, itt nem foglalkozunk a költségvetési ciklus egyéb területeivel (Sivák - Zsugyel 2015).

Jelen tanulmány első része a kapcsolódó szakirodalmat tekinti át, a második része pedig részletesen mutatja be a közpénzügyi szektorra adaptált hatékonyságjavítási eszközt.

\section{IRODALOM FELDOLGOZÁS LITERATURE REVIEW}

A gazdálkodási folyamatok újra-szervezésének és újjáalakításának igénye messzire nyúlik vissza a menedzsment szakirodalom történetében, nemcsak a tudományos területek művelöi körében, hanem a gyakorló szakemberek között is egyre nő a népszerüsége. A diszfunkcionális folyamatok átalakításának igénye egyre hatványozottabban van jelen a 21. században is, sőt, egyre szofisztikáltabb eszközök és módszerek terjednek, de mind a régi alapelvekre épül (Porter 1985).

A szükülő piacok és a növekvő verseny, valamint egy gazdasági válság folyamatos racionalizálásra, költségcsökkentésre és hatékonyságnövelésre késztetik a szervezeteket valamilyen komparatív előny reményében, ami talajt teremt a folyamatjavító módszerek fejlesztésének (Hammer 1990).

A BPA (Business Process Amelioration) módszerek fejlődése egészen az ipari korszak (17501970) kezdetleges folyamatorientációjáig vezethető vissza. Ennek az embrionális folyamatfejlesztési fázisnak a fő célja a munkaerő-megosztás, a költségek csökkentése és a termelékenység olyan technológiákkal, mint a gépesítés, a szabványosítás és az analitikus nyilvántartások. Fö eszközeik voltak a PDCA fejlesztési ciklus és a pénzügyi modellezés. A right-sizing (optimális szervezeti méret) és a szerkezetátalakítás módszereit is használták már, de ezen módszerek folyamatorientációja viszonylag alacsony, csak formális struktúrák átalakítására vonatkoztak. Irányultsága főként funkcionális, a fejlesztési célok általában inkrementálisak, és az alkalmazási gyakoriság időben elszigetelt (Grover \& Malhotra, 1997).

A hatékonyságjavító módszerek közül kiemelendő a BPR (Business Process Reengineering): üzleti folyamatok újraszervezése. A módszer megjelenését három szembetűnő változás (3C) okozta: ügyfelek (customers) felülkerekedése, verseny (competition) kiéleződése, változások (change) állandósulása. A BPR módszer egyszerüsített definíciója Hammer-Champy (2001) alapján: üzleti folyamatok alapvető újragondolása és radikális újratervezése a költség, a minőség, a szolgáltatás és a sebesség jellemzők drámai javulásának elérése érdekében.

Az üzleti folyamatok alapvető újragondolása azt jelenti, hogy a folyamatok belső szabályainak feltárása útján nem javítjuk azokat, hanem teljes egészében és mélységében vizsgáljuk őket. Radikális módon végezzük, azaz nem elegendő kismértékü változtatásokra törekedni, hanem teljesen új és lehetőleg hatékony koncepciót kell kialakítani. Végül az eredményben történő változás is nagy és jelentős kell, hogy legyen. Azon szervezeteknek javasolt a BPR módszertan alkalmazása, amelyek komoly problémákkal küzdenek (értékesítés, készlet, piaci helyzet stb.), vagy érzik a belső krízis előszelét; valamint azoknak, amelyek jól müködnek ugyan, de szeretnének radikális fejlődést elérni.

A költségvetési szervezetek működésének megítélése eltérő a szakirodalomban, de abban a legtöbb szerző egyetért, hogy a bőven vannak fejlesztési lehetőségek. Az elvárások és a javaslatok legtöbb helyen az ún. új közmenedzsment néven ismert közigazgatási reformok céljaival egyeznek meg. E reformoknak két fontos területe van: az állami szerepvállalás minimális szintre csökkentése és a belső müködési hatékonyság javítása (Pálné 2008). 
A költségvetési szervezetek gazdálkodási szempontból monopolhelyzetben vannak a közjavak „eloóllításával”, amely kockázat- és kudarckerülővé teszi a szervezet. A politikai behatások és a versenyhelyzet hiánya miatt a közszolgák sem annyira nyitottak az innovációra, mint az üzleti életben foglalkoztatottak (Pollit et al. 2007).

A sikeres, innovatív projektekhez ugyanúgy projektmenedzsment kell a költségvetési szervezeteknél, mint az üzleti szektorban. A közszférában dolgozó projektmenedzserek nem mindig tudnak azonosulni az üzleti szektorból származó teljesítmény elvárásokkal, sokkal inkább a politikai behatásokat helyezik elötérbe. Ez nagy kihívást jelent nekik a relatíve gyorsan változó szakpolitikák miatt (De Vries \& Nemec 2013).

A költségvetési szervezetek és az üzleti szektorban tevékenykedö szervezetek között az egyik alapvetö különbség a tulajdonosi forma. Míg az üzleti életben jól körül határolható egy vállalkozás tulajdonosi köre, addig a költségvetési szervezeteket a „köz” tulajdonolja az éppen hatalmon lévő politikai erő által. Boyne (2002) az alábbi pontokat azonosítja a köz/magán szervezetek között a tulajdonosi formán túl:

- Instabilitás: a politikai erőviszonyok változásának eredményeként a közszektor felső vezetése is gyakran változik.

- Komplexitás: a politikai erők által képviselt tulajdonosi szerkezet mindig újabb igényeket és stratégiai célokat fogalmazhat meg.

- Könnyü átjárhatóság: a költségvetési szervezetek túlságosan nyitottak, könnyen hatnak rájuk a szervezeten kívüli események, folyamatok.

- Versenyhelyzet hiánya vagy korlátozott léte: ha az adott közszolgáltatásnak van az üzleti életben alternatívája, akkor is a közjavak dominálnak.

Tekintettel arra, hogy a közszektorban az üzleti életben müködő folyamatok, technikák és rendszerek nem, vagy csak korlátozottan alkalmazhatók, így az itt dolgozó vezetőknek a közszektorra érvényes etikai „kódex” a legfontosabb alapelv. Ezt kell összhangba hozni a tulajdonosok mindenkori elvárásaival és a folyamatosan változó stratégiai célokkal. A közszektor menedzserei lehetnek kiváló szakértői egy adott gazdálkodási területnek, vagy befolyásos politikai kapcsolatokkal rendelkező egyének, nem tudják korrekt módon ellátni feladataikat, ha nem követik a közszolgálati etikát (Jalocha et al. 2014).

A mindenkori kormányzatnak az a célja, hogy újabb és újabb lehetőségeket keressen a költségvetési szervezetek múködési kiadásainak mérséklésére, $\mathrm{s}$ egyúttal stimulálja az innovációt a szervezeten belül is. Az új menedzsment technikák, ügyviteli eljárások, kormányzati modellek bevezetése mellett az állam nem feledkezhet el az alapfeladatai ellátásáról - pl. államhatalmi, védelmi, kulturális stb. Ezért alapvető változtatásokat csak a legmagasabb kormányzati szinten lehet elérni (Kassó 2008).

Ez egy újfajta müködési, szervezeti megközelítés, amely választ ad a tradicionális kormányzati menedzsment eszköztár hiányosságaira. Főbb pontjai a következők: a közszektor komplexitásának csökkentése a költségvetési szervezetek müködésének (belső folyamatainak) egyszerüsítésével, illetve a mag tevékenységhez igazodó organogram kialakításával, és az innováció elősegítése a tulajdonosok mobilitásának növelésével (Janssen \& Estevez 2013).

Ez egy nagyon különleges és speciális témakör a szolgáltatási rendszerek hatékonyságának analízise során, hiszen a közpénzügyi rendszerek orgver $^{3}$ környezete sokkal erősebben szabályozott folyamat szinten, mint a szolgáltatási rendszereké. A hatékonyság értelmezése és mérése mindig csak egy jól meghatározott cél ismeretében, annak szempontjából lehetséges. A közpénzügyi gazdálkodási rendszerek esetében a modell megfelelőségét (eredményességét) a következőképpen definiáljuk Kolozsi et al. 2017 alapján: ha a rendszer kimeneti állapota megegyezik (vagy egy elöre definiált tartományon belül van) a folyamat lefutása után elvárt célállapottal.

A zárt módosítású szolgáltatási folyamatok alatt olyan folyamatokat értünk, amelyeket jogszabályi, belső szabályozási, vagy minőségbiztosítási okok miatt csak nagyon kis mértékben lehet változtatni. Az ilyen közpénzügyi gazdálkodási folyamatok javítása kizárólag a belső tevékenységfolyamat átalakításával nem lehetséges, ebben az esetben más eszközöket is keresni kell, hogy a rendszer hatékonysága növekedjen.

Jelen tanulmányban kitérünk arra is, hogy a korábban vizsgált szolgáltatási rendszerek közé teljesen beilleszthetők-e a közpénzügyi gazdálkodási rendszerek, amelyek szélsőséges, egyedi jellegzetességekkel rendelkezö esetet képeznek a hatékonyságjavítási szempontból. A szolgáltatási rendszerek viszonylag szabadon módosíthatók az optimum-

3 A külső-belső hardver és szoftver elemek, szervezeti megoldások együttesét nevezzük így. 
hoz közeli múködés megvalósítása érdekében, a közpénzügyi gazdálkodási rendszerek azonban lokálisan korlátozott szervezetek.

A gazdálkodási rendszerek folyamatai a szervezetben való elhelyezkedésüktől függően, mind szerkezetükben, mind müködési jellegzetességeikben eltérőek lehetnek, és első megközelítésben igen eltérő folyamatmúködési jellemzőik vannak (Brahe 2007). Valójában, egy részletes vizsgálat során azt vehetjük észre, hogy egy dologban azonban megegyeznek. Minden folyamat esetében legalább egy „objektum” a teljes folyamaton, vagy folyamrészeken végig áramlik, és több „helyen” részben vagy egészben használja a folyamat adott helyen elérhető erőforrásait (Bloch \& Bugge 2013).

A vizsgált gazdálkodási rendszerek elemzése során megállapítottuk, hogy az említett objektum olyan adat, anyag vagy erőforrás, amely áramlik, transzformálódhat és információként is mérhető az áramlás bármely csomópontjában. Az adminisztrációs folyamatban feltárt minden olyan eseményt, amely hatással van az objektum információ jellegére, tranzakciónak nevezzük. Ezen jellegzetességnek az idökerete rögzített, van benne legalább egy adatérték (üzenet) és az adattartalma, valamint időbélyege nem módosítható. A folyamatot az határozza meg, hogy adott időkeretben, a vizsgált csomópontokon az adott objektumon milyen tranzakciók hatnak, azaz milyen tevékenységeknek kell vagy kellene megtörténnie (Bányai et al. 2015).

\section{OBJEKTUMÁRAMLÁS A GAZ- DÁLKODÁSI RENDSZEREKBEN OBJECT-FLOW IN MANAGE- MENT SYSTEMS}

Ebben a fejezetben a független transzformációk modelljéhez kapcsolódó fogalmakat, a hipotézist és a matematikai modellt és mutatjuk be.

A vizsgálatainkban csak az áramlásban résztvevő objektum időbeli állapotváltozásai játszanak szerepet. Ennek előnye, hogy a szolgáltatási- vagy közpénzügyi gazdálkodási folyamatok esetében nem tárhatók fel egyértelmüen anyagi, vagy információ eredetü áramok és a helyváltozás sem térképezhető fel. Mégis fontos egy olyan dinamikus modell megalkotása, amely leírja a gazdálkodási rendszerben végbemenő változásokat oly módon, hogy ezek bármely folyamatleírásba beilleszthetőkké váljanak. Ezáltal ugyanolyan hatékonyságjavítás érhetö el a közpénzügyi adminisztrációs folyamatokban is, mint a szolgáltatási rendszerekben.
Vizsgáljuk meg a következő objektumra vonatkozó feltételezéseket Telek - Bányai 2013 alapján:

- Alapvető tényként kezelhetö-e az, hogy bármely gazdálkodási rendszerben feltárható egy kezdeti objektum?

- $\quad$ Ez az objektum determinisztikusan vagy sztochasztikusan jön létre?

- A kezdeti objektumnak valamelyik rendszerbemeneten meg kell jelennie és minden esetben generál egy kezdeti tranzakciót.

Az nyilvánvaló, hogy minden rendszerbemeneten meg is jelenik egy objektum és vele egy transzformáció, ellenkező esetben ez a bemenet nem képezi a folyamatrendszer részét. Mivel tranzakció (esemény) objektum (,ok”) nélkül nem lehetséges, ezért igazoltnak tekintjük, hogy van kezdeti objektum és a rendszer esemény-vezérelt (Gubán 2015).

Továbbá, a kiindulási objektum (jel vagy üzenet) minden esetben végig áramlik a rendszeren, a folyamat során azonban transzformálódhat. Sőt többnyire transzformálódik is, mivel információ tulajdonsággal is rendelkezik. Azért fontos az elözőek igazolása, mert a közpénzügyi gazdálkodási rendszerekben található objektumok áramlásának modellezésére épül a hatékonyságjavítás a gyakorlatban (Mezei 2020).

Jelen tanulmány hipotézisének vizsgálatakor egy egyszerü általánosításból indulunk ki. A közpénzügyi gazdálkodási rendszerek folyamataiban az általánosságban megfigyelhető áramlásokat (pl. információ, anyag, erőforrás stb.) a vizsgált objektum helyváltoztatása jelenti (Chan \& Choi 1997). Ezek a helyváltoztatások időbeli változásokat mutatnak az objektum paraméterein és attribútumain, tehát az áramlás tekinthető objektumok helyváltoztatásának - ezt a rendszerhez viszonyított aspektusnak nevezzük. Ha a helyváltoztatás csak virtuális, azaz térbeli elmozdulás nem észlelhető (csak az objektum tulajdonságaiban bekövetkezett változások észlelhetők), így általánosabb esetben a folyamatok tekinthetők az objektumban létrejött változásként is - ezt objektum aspektusnak nevezzük.

Ez utóbbi eset több, a fizikai mozgást nélkülöző változást is képes kezelni. Ennek leggyakoribb esete az adatváltozás, amikor fizikai helyváltozás felhasználói szempontból történő elemzés esetén egyáltalán nem történik, mert a felhasználók aspektusából az adat mindig ugyanazon a helyen marad, csak ,értéke” változik. Épp ezért az elemzésekben egy objektum áramlását mindkét aspektusból azonos módon vizsgálhatjuk, eredményük ugyanaz lesz. Hasonló szemléletet mutat a szegmentált modelljeiben Gautam et al. (2017) is. 
A modellezés során a továbbiakban objektum alatt a vizsgált rendszerben állapotváltozásra képes adatot, tárgyat, információt, illetve nem anyagi jellegü elemeket értjük. Az objektumokat leíró és változtatható értékkel rendelkező jellemzőket a továbbiakban állapotjellemzönek hívjuk.

A rendszerünkben a vizsgálatokat célszerü azokon a helyeken elvégezni, ahol az objektum-változások történhetnek (pl. minőségellenőrzési pont) azaz, az objektum állapothalmazában változás áll be. Ezeket a helyeket Business Process Amelioration (BPA) módszertannak megfelelően csomópontként fogjuk kezelni.

Vizsgálatunkban csomópontnak nevezzük azokat a jól definiálható rendszerelemeket, amelybe inputként bejutó-, vagy belső objektum valamely attribútumán értékváltozás történhet. Objektum állapotváltozások sorozatát a továbbiakban folyamatnak nevezzük.

Ezek az állapotváltozások maguk is tekinthetők folyamatrendszernek. Azaz, ilyen folyamatrendszerek a már létező vizsgálati módszertan segítségével elemezhetők lesznek, ha a bennük feltárható „változásokat" tekintjük. Amennyiben alkotunk egy olyan modellt (Veres et al. 2016), amelyben az állapotváltozások egyszerü transzformációkra bonthatók, akkor már a gyakorlati állapotváltozási rendszerek is könnyen adaptálhatók lesznek a közpénzügyi gazdálkodási rendszerekre.

A cikkünk 1. hipotézise a közpénzügyi adminisztrációs folyamatokban áramló objektumokra és a közpénzügyi gazdálkodási folyamatok elemzésére fókuszál. Az 1. hipotézis a következő: „A közpénzügyi gazdálkodási rendszerek folyamataiban megfigyelhetö objektumáramlások segitségével hatékonyságjavitás végezhetö. A közpénzügyi gazdálkodási folyamatok javitásának sikere korrelációt mutat az alkalmazott módszertannal."

\section{AZ OBJEKTUMÁRAMLÁS MODELLJE OBJECT-FLOW MODEL}

Legyen $O$ egy véges állapotjellemző halmazzal (állapotváltozó halmaz) rendelkező csomópont (beleértve minden állapotjellemzöt, amit a csomópont a időintervallumban $\left[t_{1} ; t_{2}\right]$ jellemez. Amennyiben egy adott $t \in\left[t_{1} ; t_{2}\right]$ időpillanatban az $S_{i}$ állapotjellemző ,nem jellemzi” a csomópontot, annak értéke legyen $\emptyset$, ami nem valós értéket jelent, csupán szimbólum, amelyre történő minden összehasonlításban az érték lesz a mérvadó. Így az eredeti $A_{i}$ állapothalmazt a továbbiakban - a függvényszerü leírás miatt - kibővítjük. $\overline{A_{i}}=A_{i} \cup\{\varnothing\}$.
Továbbá, legyen az $O$ csomópont (a továbbiakban a (Gubán - Kása, 2014) megfelelés miatt a csomópontot objektumnak nevezzük) egy $S_{i}$ állapotjellemzője, és értékváltozását a vizsgált időintervallumban a $S_{i}(t):\left[t_{1} ; t_{2}\right] \mapsto \overline{A_{i}}$ függvény írja. A teljes objektum-változás, a

$$
S\left[t_{1} ; t_{2}\right] \rightarrow \overline{A_{1}} \times \overline{A_{2}} \times \ldots \times \overline{A_{n}}(=\mathcal{A})
$$

Felvetődik a kérdés vajon milyen változás az, amely az objektum sajátjaként tekinthetö, azaz a változás már akkora mértékü, hogy másik objektum válik belőle. Például, a fa feldolgozása során, mikor válik papírrá, azaz egy teljesen más objektummá.

A vizsgálatban legyen a $t$ időpontban $\left\langle O ; T_{O} ; S_{O}(t)\right\rangle$ az objektumunk $O$ típusú objektumtípusban $T_{O}$; az adott objektumtípus minőségében és végül az $S_{O}(t)$ állapotrendszerben. A típusváltás magában foglalhat egy állapotrendszerbeli ugrásszerü változást, objektumtípus a példában lehet farönk, deszka, faforgács, papír stb. Objektumtípus minősége, lehet kiváló minőségü fehér papír, újrahasznosított papír stb., a jellemzők értelemszerüek. Mivel maga a példa is mutatja, hogy sem a típus, sem pedig a minőség nem egyértelmü, ezért Fuzzy rendszerben kell gondolkodnunk. Egy áramlási rendszer monitorozása is csak diszkrét módszerekkel oldható meg, ezért a továbbiakban, időben diszkrét állapotváltozással foglalkozunk, amely a gyakorlatban Fuzzy, illetve neuro-fuzzy modellezéssel és szimulációval könynyen elemezhetö.

A továbbiakban a vizsgálatokat egy rögzített rendszerre végezzük el. Ez azt jelenti, nem foglalkozunk azzal, hogy milyen okok miatt müködnek az adott áramlási rendszerben a transzformációk. Legyen egy objektum-áram a vizsgált rendszerünkben $F F(t):\left[t_{1} ; t_{2}\right] \rightarrow A_{1} \times A_{2} \times \ldots \times A_{n}(=\mathcal{A})$, ahol a $\left[t_{1} ; t_{2}\right]$ a vizsgált áramlási időtartam, $A_{i}(i=1 ; 2 ; \ldots n)$ egy adott tulajdonság állapothalmaza, amely alulról is és felülről is korlátos.

Nevezzük a $t_{0} \in\left[t_{1} ; t_{2}\right]$ bekövetkezett állapotváltozás okát T transzformációnak. A transzformációk diszkrét módon jelennek meg, de hatásaikat e g y $\left[t_{0} ; t_{0}+\Delta t\right](\Delta t>0)$ fejtik ki. (Megjegyzés: az intervallumok között lehet átfedés.) Például, a hagyományos orvosi terápiák halmazának egyfajta bővítését értjük ez alatt, hiszen beleértjük a terápiák befejezése során történő hatásokat, valamint a spontán változásokat is. Ezeket, ha kell spontán transzformációk nevezzük.

Legyen $T$ Transzformáció és legyen a hatás időintervalluma $\left[t_{0} ; t_{0}+\Delta t\right](\Delta t>0)$, továbbá $t_{0}$ a kezdeti időpontban a rendszerállapot $\boldsymbol{a}_{t_{0}} \in \mathcal{A}$ az állapotváltozás függvény az $S_{i}$ tulajdonság 
$f_{i}\left(t ; \boldsymbol{a}_{t_{0}} ; t_{0}\right):\left[t_{0} ; t_{0}+\Delta t\right] \rightarrow \boldsymbol{a}_{t}(\Delta t>0)$. Ez nyilván akkor érvényes, ha mellette más Transzformáció hatása nem érvényesül a rendszerre. Tételezzük fel, hogy a rendszerben a $\left[t_{1} ; t_{2}\right]$ intervallumban véges sok hatás (és mellette véges sok mellékhatás) érvényesül. Így az adott $t \in\left[t_{1} ; t_{2}\right]$ időpontban a Transzformáció hatások általános alakban a következő módon adhatók meg:

$$
\varphi(t):\left[t_{1} ; t_{2}\right] \rightarrow \mathcal{A} .
$$

A fenti függvény nyilvánvalóan nem lehet folytonos, mivel egy belépö Transzformáció azonnal ugrásszerủ változást okozhat, amely következményeként egy szakaszosan legalább egyszer differenciálható $n+1$, dimenziós felületet kapunk.

A valós állapot az $S_{i}$ tulajdonságon nemcsak az aktuális transzformációtól függ, hanem az időintervallumra eső más transzformációk hatásától. Ez a hatás nagyon eltérő lehet. A legjellemzőbbek:

$$
\begin{gathered}
F_{i}(t):=\sup _{\delta_{j}(t)=1}\left(f_{j}(t)\right) ; F_{i}(t):= \\
=\inf _{\delta_{j}(t)=1}\left(f_{j}(t)\right) ; F_{i}(t):=\sum_{\delta_{j}(t)=1} \lambda_{j} f_{j}(t) .
\end{gathered}
$$

Vizsgáljuk azt az egyszerủ esetet, amikor csupán egy Transzformáció hat.

Egy Transzformáció jó, ha vizsgált idő alatt aszimptotikus tulajdonságot mutat, és az érték egy elöre rögzített értéknek felel meg, azaz $\lim _{t \rightarrow t_{2}} f_{i}(t)=$ $=a_{i, t_{2}}\left(\in A_{i}\right)$. Sőt stabilitást is mutat, azaz $\left(t_{2}+\Delta t ; t_{2}\right)$ intervallumban, a három közül valamelyik (elvárt) tulajdonságnak eleget tesz: legyen $\varepsilon>0$ előre rögzített és meghatározott érték, $\left|f_{i}(t)-a_{i ; t_{2}}\right|<\varepsilon ; f_{i}(t)$ $-a_{i ; t_{2}}<\varepsilon$ vagy $a_{i ; t_{2}}-f_{i}(t)<\varepsilon$. Elegendő az első esettel foglalkozni a másik kettőre hasonlóan alkalmazhatók a vizsgálatok.

Feltételezhető a $T$ Transzformáció hatásának sebessége (állapotváltozás) arányos az aktuális (mért) és ideális állapot különbségével (egy megadott intervallumban). Ekkor a hatás differenciál egyenlete (legyen az aktuális állapot $a_{0}$ és az ideális $\left.a_{o p t}\right)$

$$
\frac{d a}{d \tau}=k \Delta a
$$

ahol $\frac{d a}{d \tau}$ a transzformációnak a hatásának sebessége, $\quad \Delta a=a-a_{\text {opt }}$ az állapot ás az ideális állapot közötti eltérés (saját dimenzióban), $k$ arányossági tényező.
A fenti (4) egyszerü differenciálegyenlet megoldása

$$
a(\tau)=\left(a_{0}-a_{o p t}\right) e^{k \tau}+a_{\text {opt }} .
$$

Ezzel az adott pillanatban a Transzformáció egyedi hatása meghatározható. Az orvosi példát folytatva, ezáltal azt is megkapjuk, hogy ,jó" irányba halad-e „kezelés”.

Nyilvánvaló, hogy egy Transzformáció nem feltétlen csak egy állapotra hat, hanem más állapotokra is. Ezeket - ha nem célzottak - mellékhatásoknak fogjuk hívni. Így egy Transzformáció a következő módon általánosítható.

Legyen $T$ Transzformáció és legyen a hatás idöintervalluma $\left[t_{0} ; t_{0}+\Delta t\right]$, az állapotváltozás függvény az $S_{i}$ tulajdonság $f_{i}(t):\left[t_{0} ; t_{0}+\Delta t\right] \rightarrow$ $\rightarrow \mathcal{A}(\Delta t>0)$, ahol $\left(\Delta t=\max \left(\Delta t_{i} ; 1=1 ; 2 ; \ldots n\right)\right.$ azaz a leghosszabb idejü hatás vagy mellékhatás időtartama. Az adott időpontban ható Transzformációk eredő hatása.

\section{Transzformációk szorzata Multiplication of transformations}

Legyenek $T_{1} ; T_{2} ; \ldots ; T_{k}, k>2$ a $\left[t_{1} ; t_{2}\right]$ intervallumban ,ható" összes transzformáció, $\varphi_{T_{i}}(t)=$ $\left\langle a_{1 t}^{T_{i}} ; a_{2 t}^{T_{i}} ; \ldots ; a_{n t}^{T_{i}}\right\rangle ; i=1 ; 2 ; \ldots ; k$ hatásfüggvénye. $\mathcal{T}=T_{1} T_{2} \cdot \ldots \cdot T_{k}$ transzformációk szorzatán a $t$ időpontban azt a hatásfüggvényt értjük, amely megadja az aktuális állapotrendszert: $\varphi_{\mathcal{T}}(t)=$ $\left\langle a_{1 t} ; a_{2 t} ; \ldots ; a_{n t}\right\rangle ; t \in\left[t_{1} ; t_{2}\right]$.

\section{Transzformációk függetlensége Idependency of transformations}

Két Transzformáció $T_{1} ; T_{2}$ páronként független, ha a Transzformációk csak egyedül hatnak a $\left[t_{1} ; t_{2}\right]$ időintervallumban.

Azaz legyen $\varphi_{T_{1}}(t)=\left\langle a_{1 t}^{T_{1}} ; a_{2 t}^{T_{1}} ; \ldots ; a_{n t}^{T_{1}}\right\rangle$; és $\varphi_{T_{2}}(t)=\left\langle a_{1 t}^{T_{2}} ; a_{2 t}^{T_{2}} ; \ldots ; a_{n t}^{T_{2}}\right\rangle$; a két transzformáció hatásfüggvénye, valamint legyen $\varphi_{T_{1} T_{2}}(t)=$ $=\left\langle a_{1 t} ; a_{2 t} ; \ldots ; a_{n t}\right\rangle$ a Transzformációk együttes érvényesülésének (továbbiakban: szorzatuk) hatásfüggvénye. Vegyük a következő származtatott állapotfüggvényt: 


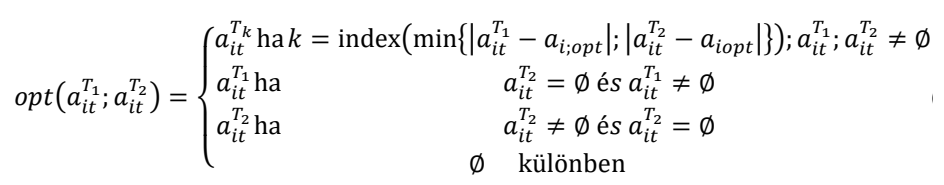

A két Transzformációt függetlennek nevezzük (jelölésben $T_{1} \uparrow T_{2}$ ), ha $a_{i t}=\operatorname{opt}\left(a_{i t}^{T_{1}} ; a_{i t}^{T_{2}}\right)$, minden $i=1 ; 2 ; \ldots ; n$. A definícióból következik a reláció szimmetrikus.

A reflexivitás vizsgálatához néhány feltétellel élni kell. Egyrészt egy transzformáció megjelenhet a $\left[t_{1} ; t_{2}\right]$ időintervallumban akár többször is eltérő időpillanatban, ekkor az állapotokra történő hatásuk nem lesznek függetlenek. (Például az aszimptotikus csillapodó hatás esetén egy impulzus megváltoztathatja az aszimptotikus viselkedést, vagy az aszimptotát.) Egy esetben lehetne reflexív a függetlenség, ha egyidejü azonos hatás egyetlen hatásként jelenne meg a rendszerben - azaz a rendszer redundancia szürővel rendelkezik. Ez az elvárás nem igazán életszerü, tehát megállapíthatjuk a reláció nem reflexív. A továbbiakban csak és kizárólag olyan transzformációkat használunk, amelyek irreflexívek.

A tranzitivitás megvizsgálása is fontos kérdés. A hétköznapi életböl vett példák esetében gyakran találhatunk olyan eseteket, amelyek nem tranzitívak. Elképzelhető, hogy az A és a B gyógyszernek, valamint a $\mathrm{B}$ és $\mathrm{C}$ gyógyszereknek páronként nincs egymásra semmilyen hatása a kezelések során. Az A gyógyszer valamely komponensére azonban a $\mathrm{C}$ hatással van, ezért a kezelés során esetleg együtt nem is használhatók. Megvizsgálva a fenti definíciót konstruálható olyan eset, amelyben a tranzitivitás nem teljesül. Legyen a $\bar{A}_{1}=\bar{A}_{2}=\{\emptyset ; 0 ; 1 ; 2\}$; $\operatorname{opt}\left(\bar{A}_{1}\right)=\operatorname{opt}\left(\bar{A}_{2}\right)=0 ; \quad \varphi_{T_{1}}(t)=\langle 1 ; 0\rangle ;$ és $\varphi_{T_{2}}(t)=\langle 0 ; 1 ;\rangle$; két transzformáció hatásfüggvénye (6) alapján, valamint legyen $\varphi_{T_{1} T_{2}}(t)=\langle 1 ; 1\rangle$;

$$
\begin{gathered}
\varphi_{T_{1}}(t) \cdot \varphi_{T_{2}}(t)= \\
=\left\langle\operatorname{opt}\left(a_{1 t}^{T_{1}} ; a_{1 t}^{T_{2}}\right) ; \operatorname{opt}\left(a_{1 t}^{T_{1}} ; a_{1 t}^{T_{2}}\right)\right\rangle= \\
=\langle 0 ; 0\rangle \neq\langle 1 ; 1\rangle=\varphi_{T_{1} T_{2}}(t) .
\end{gathered}
$$

Tehát nem tranzitív a függetlenségi reláció.

A fenti definíció kiterjeszthető tetszőleges számú transzformáció függetlenségére is, azaz egy transzformáció független egy transzformáció rendszertől, ha a transzformáció a transzformáció rendszer minden elemétől páronként független, azaz legyen $T$ és $\left(T_{1} ; T_{2} ; \ldots ; T_{k}\right)$.
Fontos megvizsgálni, hogy a Transzformációk együttes hatása esetén (egy adott a $t \in\left[t_{1} ; t_{2}\right]$ időpillanatban) vajon felbonthatók-e független Transzformációk szorzatára.

2. hipotézis: „több együttes Transzformáció szorzat-transzformációja felbontható független Transzformációk szorzatára".

\section{Bizonyítás \\ Demonstration}

Legyenek $T_{1} ; T_{2} ; \ldots ; T_{k}, k>2$ a $\left[t_{1} ; t_{2}\right]$ intervallumban ,ható” összes transzformáció, és legyen $\mathcal{T}$ a szorzat-transzformációjuk: $\varphi_{\mathcal{T}}(t)=\left\langle a_{1 t} ; a_{2 t} ; \ldots\right.$; $\left.a_{n t}\right\rangle ; t \in\left[t_{1} ; t_{2}\right]$ hatásfüggvénnyel. Továbbá hozzuk létre a $\widehat{T}_{i} ; i=1 ; 2 ; \ldots n$ transzformációkat úgy, hogy hatás-függvényük $\varphi_{T_{i}}(t)=\left\langle\emptyset ; \ldots ; a_{i t} ; \ldots ; \emptyset\right\rangle$.

$\mathrm{Az}$ nyilvánvaló, hogy ezen transzformációk függetlenek lesznek, hiszen hatásfüggvényeikre érvényes $\varphi_{T_{i}}(t)=\left\langle\emptyset ; \ldots ; a_{i t} ; \ldots ; \emptyset\right\rangle ; \varphi_{T_{i j}}(t)=\langle\emptyset ; \ldots ;$ $\left.a_{j t} ; \ldots ; \emptyset\right\rangle$. és $i \neq j ; i, j=1 ; 2 ; \ldots ; k$ és legyen $i<j$, ekkor

$$
\operatorname{opt}\left(a_{l t}^{T_{1}} ; a_{l t}^{T_{2}}\right)=\left\{\begin{array}{ccc}
a_{i t} & h a & l=i \\
a_{j t} & h a & l=j \\
\emptyset & k \ddot{u l} l o ̈ n b e n & l \neq i ; j
\end{array}\right.
$$

ebből

$$
\begin{gathered}
\bar{T}_{\imath} \bar{T}_{j}: \varphi_{T_{i}}(t) \cdot \varphi_{T_{j}}(t)=\left\langle\emptyset ; \ldots ; a_{i t} ; \ldots ; \emptyset\right\rangle \cdot \varphi_{T_{i}}(t)= \\
\left\langle\emptyset ; \ldots ; a_{j t} ; \ldots ; \emptyset\right\rangle=\left\langle\emptyset ; \ldots ; a_{j t} ; \emptyset ; \ldots ; a_{j t} ; \ldots ; \emptyset\right\rangle
\end{gathered}
$$

transzformáció szorzatot kapunk, de ez megegyezik $\left\langle\emptyset ; \ldots ;\right.$ opt $\left(a_{i t}^{\bar{T}_{1}} ; a_{i t}^{\bar{T}_{2}}\right) ; \emptyset ; \ldots ;$ opt $\left.\left(a_{j t}^{\bar{T}_{1}} ; a_{j t}^{\bar{T}_{2}}\right) ; \ldots ; \emptyset\right\rangle$, tehát $\bar{T}_{1} \uparrow \bar{T}_{2}$.

Ezzel igazoltuk, hogy felbontható páronként független Transzformáció rendszerrel a jelenlegi Transzformáció rendszer.

Mivel a fenti hozzárendelés minden $t \in\left[t_{1} ; t_{2}\right]$ elvégezhetö, definiáljuk a $\hat{T}_{i} ; i=1 ; 2 ; \ldots n$ transzformációkat úgy, hogy a hatásfüggvényük: $\varphi_{T_{i}}(t)=\varphi_{T_{i} t} ; t \in\left[t_{1} ; t_{2}\right]$.

$\mathrm{Az}$ így a kapott függvények kielégítik a függetlenség definícióját minden időpontban, ezáltal a $\widehat{T}_{i} ; i=1 ; 2 ; \ldots n$ generált transzformációk az eredeti transzformációk hatásait valósítják meg és független transzformációk lesznek. 
Amennyiben elfogadjuk fenti hipotézist, akkor a transzformációs hatásfüggvény felírható az adott állapotra az alábbi alakban:

$$
\varphi_{T_{i}}(t)=\sum_{j=1}^{k} \alpha_{j}(t) ; t \in\left[t_{1} ; t_{2}\right] ; i=1 ; 2 ; \ldots n
$$

A fenti modell szimulációk alkalmazását követően a közpénzügyi szervezeteknél a gyakorlatban is alkalmazható hatékonyságjavitó eszközzé tehetö. Azaz, segitségével leképezhetö a folyamatrendszer váza, és ezen belül az alapvetö folyamatok, amelyek „önállóan” képesek müködni.

\section{ÖSSZEGZÉS SUMMARY}

A közpénzügyi folyamatok javítása nagy kihívást jelent a téma iránt érdeklődőknek, mert a közpénzügyi folyamatok nagyon szabályozottak. Ez egyrészt a jogszabályi környezetet jelenti, másrészt az azon alapuló kötött, belső szabályozást. Jelen tanulmányban megjelenő független transzformációk modelljének kidolgozásával lehetőség nyílik a korábbi kutatás során elért tudományos eredmények alkalmazására a közpénzügyi adminisztrációs folyamatokban.

A kutatási eredmények azt mutatják, hogy mind a müszaki-, a szolgáltatási- és a közpénzügyi gazdálkodási rendszerek együttesen kezelhetők folyamatjavítás szempontjából. Amennyiben a közpénzügyi gazdálkodási folyamatokban feltárt folyamatokat nem a hagyományos áramlási szempontból vizsgáljuk, hanem a belső állapotváltozások aspektusából, akkor a kezelésük, javításuk ugyanazon a módon oldhatók meg, mint más sokkal rugalmasabb szolgáltatási folyamatrendszerek esetében.

A tanulmányban bemutatott közpénzügyi adminisztrációs folyamatok szélsőséges, egyedi jellegzetességgel rendelkező esetet képeznek hatékonyságjavítási szempontból, mert az általános szolgáltatási rendszerek viszonylag szabadon módosíthatók az optimumhoz közeli múködés megvalósítása érdekében. A közpénzügyi gazdálkodási rendszerek azonban lokálisan korlátozott rendszerek.

Ez csak az első vizsgálatok során okoz komolyabb meglepetést, amennyiben jobban betekintünk a rendszert leíró folyamatvázba, akkor azt tapasztaljuk, hogy ugyanazon módszerekkel és megoldásokkal tudjuk a közpénzügyi rendszereket is kezelni, mint bármely más gazdálkodási folyamatrendszert, legfeljebb korlátozott hatékonysággal. A folyamatelemzések azt mutatták, hogy a folyamatok objektumáramlási szempontból szeparáltan kezelhetők, azaz a független transzformációk modelljének használatával jelentősen javíthatjuk azokat.

A legtöbb gondot egy gazdálkodási folyamatrendszer esetében a szűkkeresztmetszeti csomópontok jelentik, ezért kiemelten kell ezekre fókuszálni, és a lehetséges folyamatjavításokat elsősorban itt elvégezni. A gyakorlatban ez nem képzelhetö el izolált módon, hanem valamennyi érintett csomópontban el kell végezni a beavatkozást. A szervezeti változások kivitelezésekor szükséges alkalmazni a független transzformációk modelljét, hogy kizárólag ,jó irányba” és „,mellékhatás-mentesen” módosítsunk a folyamatokon. A modell közpénzügyi gazdálkodási rendszerre történő alkalmazása azt eredményezheti, hogy a felelős szervezeti egységek átláthatóbbak lesznek, és a folyamatjavítások is könnyebben elvégezhetök anélkül, hogy a jogszabályi elöírásokat megszegnénk.

Matematikai jelölések (Mathematical notation): $A$ : állapothalmaz

$F F$ : objektum-áram

$O$ : csomópont

$S:$ állapotjellemzö

$t$ : időpont

T: transzformáció

$\varphi_{T_{1}}(t):$ transzformáció hatásfüggvénye

$\mathcal{T}$ : transzformációk szorzata 


\section{HIVATKOZÁSOK REFERENCES}

Bányai T., Veres P. and Illés B. (2015), "Heuristic Supply Chain Optimization of Networked Maintenance Companies", Procedia Engineering, 100, 46-55 DOI: 10.1016/j.proeng.2015.01.341

Bloch, C. and Bugge, M.M. (2013), "Public sector innovation - From theory to measurement", Structural Change and Economic Dynamics, 27, 133-145 DOI: 10.1016/j.strueco.2013.06.008

Boyne, G. (2002), "Public and private management. What's the difference?", Journal of Management Studies, 39, 97-122 DOI: 10.1111/1467-6486.00284

Brahe, S. (2007), BPM on Top of SOA: Experiences from the Financial Industry, In Alonso, P. D. G. and Rosemann, M. (Eds.), Business Process Management, 96-111, Heidelberg: Springer

Chan, S. L. and Choi, C. F. (1997), "A conceptual and analytical framework for business process reengineering", International Journal of Production Economics, 50(2-3), 211-223 DOI: 10.1016/s0925-5273(97)00042-x

De Vries, M. and Nemec, J. (2013), "Public sector reform: an overview of recent literature and research on NPM and alternative paths", International Journal of Public Sector Management, 26(1), 4-16 DOI: 10.1108/09513551311293408

Gautam, S., Maiti, J., Syamsundar, A. and Sarkar, S. (2017), "Segmented point process models for work system - safety analysis", Safety Science, 95, 15-27 DOI: 10.1016/j.ssci.2017.01.009

Grover, V. and Malhotra, M. (1997), "Business process reengineering: A tutorial on the concept, evolution, method, technology and application", Journal of Operations Management, 15(3), 193-213 DOI: 10.1016/s0272-6963(96)00104-0

Gubán Á. (2015), Gazdasági folyamatok entrópiája és mérhetősége. In Solt K (szerk.), Alkalmazott tudományok II. fóruma: Konferenciakötet, BGF, Budapest, 170-176

Gubán Á., Kása R. (2014), "Conceptualization of fluid flows of logistificated processes", Advanved Logistics Systems: Theory and practice, 7(2), 27-24.

Hammer, M. (1990), “Reengineering work: Don’t automate, obliterate", Harvard Business Review, 68(7), 104-112

Hammer, M. and Champy, J. (2001), Reengineering the corporation: A Manifesto for Business Revolution, Harper-Collins Publishers, New York

Jalocha, B., Kraneb Hans, P., Ekambaram, A. and Prawelska-Skrzypek, G. (2014), "Key competences of public sector project managers", Procedia - Social and Behavioral Sciences, 119, 247-256 DOI: 10.1016/j.sbspro.2014.03.029

Janssen, M. and Estevez, E. (2013), "Lean government and platform-based governance Doing more with less", Government Information Quarterly, 30(S1), 1-8 DOI: 10.1016/j. giq.2012.11.003

Kassó Zs, (2008), Átláthatóság, elszámoltathatóság, hatékony gazdálkodás. Megbízható számviteli adatok nélkül lehetséges-e? Buday-Sántha Attila (szerk.): Önkormányzatok gazdálkodása - helyi fejlesztés. Pécsi Tudományegyetem Közgazdaságtudományi Kar, Pécs

Kolozsi P.P., Lentner Cs., Parragh B. (2017), “Közpénzügyi megújulás és állami modellváltás Magyarországon,. Polgári Szemle, 13(4-6), 28-51 DOI: 10.24307/psz.2017.1204

Mezei Z. (2020), Közpénzügyi folyamatok modelljének helye a szolgáltatási folyamatmodellekben, Doktori értekezés, PTE Regionális Politika és Gazdaságtan Doktori Iskola: Pécs

Pálné Kovács I. (2008), Helyi kormányzás Magyarországon, Dialog Campus Kiadó, Budapest

Pollit, C., van Thiel, S. and Homburg V. (ed.) (2007), New public management in Europe: Adaption and alternatives, Palgrave Macmillan, Hampshire DOI: 10.1057/9780230625365

Porter, M. E. (1985), The Competitive Advantage: Creating and Sustaining Superior Performance, Free Press, New York

Sivák J., Zsugyel J. (2015), "Közpénzügyi feladat- és forrásmegosztási gyakorlat értékelése az OECD ajánlásainak és néhány kelet-közép-európai ország tapasztalatainak tükrében", Prosperitas, 2(1), 43-61

Telek, P., Bányai, T. (2013), "Complex design of integrated material flow systems" Advanced Logistic Systems. Theory and Practice, 7(1), $105-110$

Veres, P., Bányai, T. Illés, B. (2016), Route planning among non-pre-defined objects, In $9^{t h}$ International Doctoral Workshop on Logistics (ed. Gerecke A.), Magdeburg: Otto von Guericke University, 65-70 
Gubán Ákos, tanszékvezető, föiskolai tanár

Guban.Akos@uni-bge.hu

Budapesti Gazdasági Egyetem

Mezei Zoltán, PhD

zoltanmezei@outlook.com

Pécsi Tudományegyetem

\section{Modelling of public finance administration processes}

\section{THE AIMS OF THE PAPER}

Identifying and modelling objects/information flowing through business systems is a key topic in examining the efficacy of public finance administration processes. One of the important scientific results of the research was the development of mathematical models applicable to service processes. It is a process rationalization method based on heuristic simulation that is capable of efficiently reorganizing not only processes but also their connections and the object-flowing between these nodes by reorganizing service processes.

Improving public finance processes is a major challenge for those interested in the topic, as public finance processes are highly regulated. This means, on the one hand, the legal environment and, on the other hand, the bound, internal regulation based on it. The purpose of this study is to present a new mathematical application, which is better suited to the public finance management system, using the previous scientific results (improvement of service processes) in the field of efficiency improvement.

\section{METHODOLOGY}

In the applied mathematical model, we primarily characterize the state changes in the nodes from process and flow aspects, thus creating interdependent transformation systems. If the processes disclosed herein are not considered from the conventional flow point of view, but from the aspect of internal state changes, their treatment and repair can be solved in the same way as in other more flexible service process systems.

\section{MOST IMPORTANT RESULTS}

Process analyses have shown that processes can be handled separately from an object-flow perspective, that is, we can significantly improve them using the model of independent transformations. This is also valid for highly regulated process systems - public finance administration processes. Mapping the model to a public finance administration system will result in more transparent organizational units and easier process improvements without breaking regulatory requirements.

\section{RECOMMENDATIONS}

In working management systems, no process improvement measure can be conceived in an isolated manner, but targeted interventions should be carried out at all relevant nodes. When implementing organizational changes, it is necessary to apply the model of independent transformations to modify the processes only in the "good direction" and "without side effects".

Following the introduction, this paper focuses on reviewing the literature, the second part detailing the efficiency improvement tool developed to the public finance sector. A summary concludes the study where we evaluate the results obtained.

Keywords: efficacy development, public finance, process, object-flow, modelling 